\title{
Efficacy and Tolerability of Gabapentin in Adults with Sleep Disturbance in Medical Illness: A Systematic Review and Meta-analysis
}

\author{
Guang Jian Liu', Md Rezaul Karim ${ }^{1}$, Li Li Xư ${ }^{1}$, Song Lin Wang ${ }^{1}$, Chao Yang ${ }^{2}$, Li Ding ${ }^{1}$ and \\ Yun-Fu Wang ${ }^{1 *}$
}

${ }^{1}$ Department of Neurology, Taihe Hospital, Hubei University of Medicine, Shiyan, China, ${ }^{2}$ Department of Neurology, Wuhan Dongxihu District People's Hospital, Wuhan, China

OPEN ACCESS

Edited by:

Con Stough,

Swinburne University of

Technology, Australia

Reviewed by:

Christine Dugovic,

Janssen Research \&

Development, L.L.C.,

United States

Robert L. Barkin,

Rush University Medical Center/Northshore University Health System, United States

*Correspondence:

Yun-Fu Wang

wyfymc@sina.com

Specialty section:

This article was submitted to Neuropharmacology,

a section of the journa

Frontiers in Neurology

Received: 27 April 2017 Accepted: 16 June 2017

Published: 14 July 2017

Citation:

Liu GJ, Karim MR, Xu LL, Wang SL, Yang C, Ding L and Wang Y-F (2017) Efficacy and Tolerability of Gabapentin in Adults with Sleep Disturbance in Medical Illness: A Systematic Review and Meta-analysis.

Front. Neurol. 8:316

doi: 10.3389/fneur.2017.00316
Background and purpose: The aim of this study was to systematically review the efficacy and tolerability of gabapentin in the treatment of sleep disturbance in patients with medical illness.

Methods: PubMed was searched for randomized, double-blinded, placebo-controlled trials that reported sleep changes during gabapentin treatment up to November 2015.

Findings: This review included 26 studies involving 4,684 participants. Except for Composite Endpoint 3 [standardized mean difference $(S M D)=0.09$, 95\% confidence interval $(\mathrm{Cl})$ : $-0.05-0.22]$ compared with the placebo group, the gabapentin group showed superior outcomes on our endpoints: Composite Endpoint 1 (SMD $=0.50$, 95\% Cl: 0.28-0.71), Composite Endpoint 2 (SMD $=-0.53,95 \% \mathrm{Cl}:-0.77$ to -0.30 ), Composite Endpoint 4 (SMD = -0.38, 95\% Cl: -0.58 to -0.19), Composite Endpoint 5 [risk ratio $(R R)=1.79,95 \% \mathrm{Cl}: 1.24-2.58]$, and Composite Endpoint $6(R R=0.48,95 \%$ $\mathrm{Cl}$ : 0.32-0.72). However, the patients in the gabapentin group showed worse tolerance than those in the placebo group ( $\mathrm{RR}=1.38,95 \% \mathrm{Cl}: 1.08-1.76)$.

Implications: This study is the first to systematically assess the clinical value of gabapentin for the treatment of sleep disorders. We found that regardless the type of sleep outcomes, gabapentin displayed stable treatment efficacy for sleep disturbance in patients with medical illness. However, when an average dose of approximately 1,800 mg/day was used, the risk of treatment discontinuation or drug withdrawal was relatively high. We recommend that further studies confirm these findings in patients with primary sleep disorders.

Keywords: sleep disturbance, gabapentin, efficacy, tolerability, meta-analysis

\section{INTRODUCTION}

Sleep disorders have been always a disturbing public health issue, not only because they affect quality of life, increase the patient's risk of cardio-cerebrovascular disease $(1,2)$ and death $(2,3)$, weaken social productivity, and increase medical burdens $(4,5)$ but also because unlike other diseases with a phase-wise pattern, they cannot be cured using multiphase treatment. Although phenobarbital, benzodiazepine hypnotics, Z-drugs, antidepressants, and 
melatonin receptor agonists can all contribute to a certain extent $(6,7)$, few of these treatments can either restore patients' normal sleep structure or completely cure sleep disorders.

Gabapentin, an apha-2-delta voltage-gated calcium channel ligand (8) that is widely used for the treatment of epilepsy, neuropathic pain, and restless legs syndrome, can enhance slowwave sleep in both normal individuals (9) and epileptic patients $(10,11)$ and can improve slow-wave sleep and sleep efficiency and reduce nighttime awakening in patients with primary sleep disorders (12). However, these findings have not been verified with randomized controlled trials. Clinical studies have revealed that gabapentin could improve the objective and subjective outcomes of sleep disturbance in patient with medical illness (13-37). Gabapentin Enacarbil (GEn) or XP13512 is a prodrug of gabapentin, used as an anticonvulsant and for pain relief in postherpetic neuralgia. This new formulation of gabapentin was designed for increased oral bioavailability over gabapentin. It provides reliable drug absorption and consistent bioavailability (16). Nevertheless, the results derived from these studies had certain inconsistencies and did not undergo any systematical evaluation. Through a systematic review of the use of gabapentin to treat restless legs syndrome, neuropathic pain, alcohol dependence, hot flashes in menopause, fibromyalgia, phantom limb pain, human immunodeficiency virus (HIV)associated sensory neuropathies, and bipolar disorder, this study attempted to evaluate the efficacy and tolerability of gabapentin for the treatment of sleep disturbance in patients with medical illness.

\section{MATERIALS AND METHODS}

This systematic review and meta-analysis were performed according to the Preferred Reporting Items for Systematic Reviews and Meta-Analyses statement (PRISMA) (38). There are no ethical issues involved in our study because our data were based on published studies.

\section{Data Sources and Search}

PubMed was searched for all clinical trials related to the present research topic (up to November 8, 2015). The keywords selected from the Medical Subject Headings (MeSH) included intervention, study type, and endpoint event. The search range was "title/ abstract/keywords." No language restrictions were applied. In addition, we screened the reference lists of all included trials to identify additional eligible studies. Detailed information regarding the search terms used in the literature search is provided in the Supplementary Material.

\section{Study Selection \\ Eligible Trials}

(1) Participants: all included patients were 18 years or older and had/did not have a record of baseline sleep status; (2) intervention: the patients in the treatment group received gabapentin, gabapentin enacarbil, or XP13512 (Gabapentin), and the patients in the control group received placebos with a treatment duration of at least 7 days; (3) endpoints: all included trials reported sleep changes and treatment discontinuation or drug withdrawal events that were possibly or probably related to the study drugs; (4) study type: randomized, double-blinded, controlled trials were included.

\section{Data Extraction}

Using a unified form, two investigators independently extracted the data and created the data spreadsheet, which were then cross-checked to ensure data accuracy. Disagreements were resolved by consensus. The extracted data mainly included the six composite endpoints and treatment discontinuation or drug withdrawal events that were possibly or probably related to the study drugs.

\section{Endpoint Definitions}

Because of the diversity of outcomes reported in the included trials, only a limited number of trials provided data that could be pooled for each meta-analysis. To reach a sufficient statistical level, we introduced the concept of "composite endpoint" to pool the data related to sleep outcomes with similar significance and a consistent direction.

Based on the treatment outcomes and relevant data provided by the original trials, seven composite endpoints were analyzed for evaluation. Composite Endpoints 1-6 were used to evaluate the efficacy of gabapentin, and Composite Endpoint 7 was used to evaluate treatment discontinuation or drug withdrawal events that were possibly or probably associated with gabapentin. Composite Endpoints 1-4 indicated sleep improvement after treatment. Specifically, Composite Endpoint 1 represented the net increase in the evaluation indices provided in the trials in which the index values increased, but the baseline values were not provided. Composite Endpoint 2 represented the net decrease of evaluation indices provided in the trials in which the index values decreased but the baseline values were not provided. Composite Endpoint 3 and Composite Endpoint 4 represented

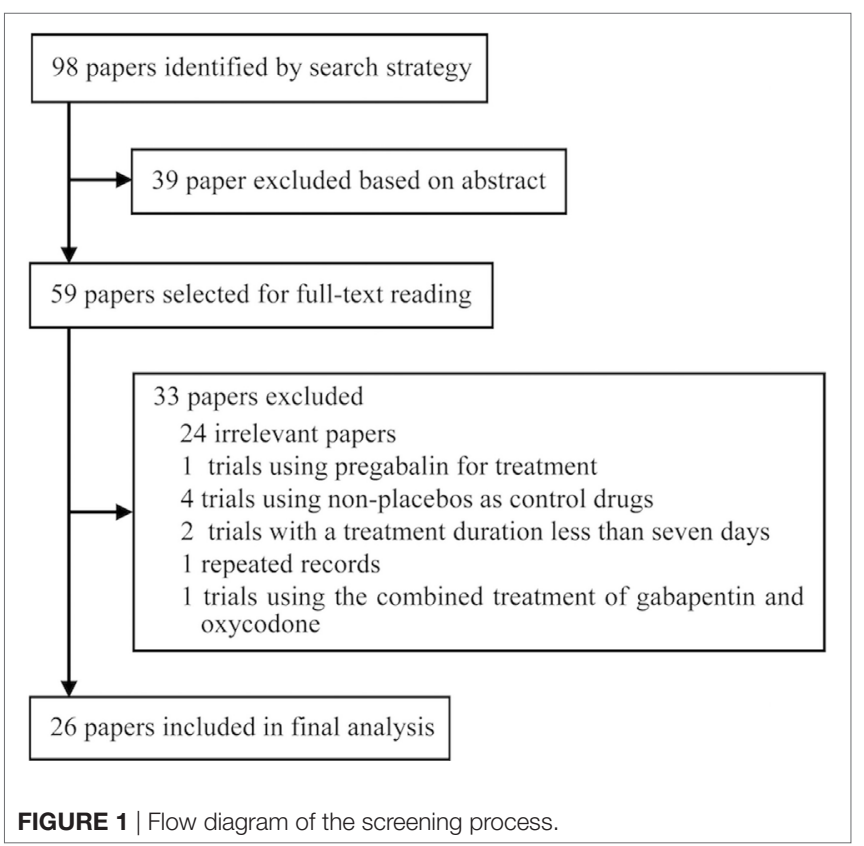


TABLE 1 | Characteristics of the included studies.

\begin{tabular}{|c|c|c|c|c|c|c|c|c|c|}
\hline \multirow[t]{2}{*}{ Reference } & \multicolumn{5}{|c|}{ Participants } & \multicolumn{2}{|l|}{ Intervention } & \multirow[t]{2}{*}{ Sleep outcome } & \multirow{2}{*}{$\begin{array}{l}\text { Study design and } \\
\text { treatment duration } \\
\text { (weeks) }\end{array}$} \\
\hline & Diagnoses & $\begin{array}{l}\text { Sample } \\
\text { size }\end{array}$ & Age (years) $^{a}$ & $\begin{array}{l}\text { Male } \\
(\%)\end{array}$ & $\begin{array}{l}\text { Illness } \\
\text { duration } \\
\text { (years) }\end{array}$ & Gabapentin group & Control group & & \\
\hline $\begin{array}{l}\text { Anton } \\
\text { et al. (13) }\end{array}$ & $\begin{array}{l}\text { Alcohol } \\
\text { dependence }\end{array}$ & 100 & $44.82 \pm 9.53$ & 82.45 & $N R$ & $\begin{array}{l}\text { Gabapentin combined with naltrexone } \\
\text { ( } 50 \mathrm{mg} / \text { day); gabapentin: the initial } \\
\text { dose was } 300 \mathrm{mg} \text { prior to bedtime, } \\
\text { increased to } 1,200 \mathrm{mg} / \text { day at night } \\
\text { from the fifth day }\end{array}$ & Identical placebo & $\begin{array}{l}\text { Insomnia sleep index (42), } \\
\text { Epworth Sleepiness Scale } \\
\text { (43); adverse effects }\end{array}$ & $\mathrm{RCT} ; 6$ \\
\hline $\begin{array}{l}\text { Brower } \\
\text { et al. (41) }\end{array}$ & $\begin{array}{l}\text { Alcohol } \\
\text { dependence }\end{array}$ & 21 & $\begin{array}{l}46(30.8-60)^{b /} \\
44(41-54)^{b}\end{array}$ & 52.38 & NR & $\begin{array}{l}\text { Gabapentin: the initial oral dose was } \\
300 \mathrm{mg} 45 \mathrm{~min} \text { before bedtime, } \\
\text { increased to } 1,500 \mathrm{mg} / \text { day at bedtime } \\
\text { within } 10 \text { days }\end{array}$ & Identical placebo & $\begin{array}{l}\text { Sleep problems } \\
\text { questionnaire; Sleep } \\
\text { diaries; Polysomnography } \\
\text { parameters; adverse effects }\end{array}$ & $\mathrm{RCT} ; 6$ \\
\hline $\begin{array}{l}\text { Hahn } \\
\text { et al. (21) }\end{array}$ & $\begin{array}{l}\text { Human } \\
\text { immunodeficiency } \\
\text { virus-associated } \\
\text { sensory } \\
\text { neuropathies }\end{array}$ & 25 & $\begin{array}{l}46(27-59)^{b /} \\
44(35-61)^{b}\end{array}$ & 80 & 0.76 (median) & $\begin{array}{l}\text { Gabapentin: the dose was adjusted } \\
\text { every } 4 \text { days until it reached } 1,200 \mathrm{mg} / \\
\text { day after more than } 2 \text { weeks }\end{array}$ & Matching placebo & $\begin{array}{l}\text { Mean sleep interference } \\
\text { scorec; adverse effects }\end{array}$ & $\mathrm{RCT} ; 4$ \\
\hline $\begin{array}{l}\text { Rowbotham } \\
\text { et al. (30) }\end{array}$ & $\begin{array}{l}\text { Postherpetic } \\
\text { neuralgia }\end{array}$ & 229 & $\begin{array}{l}73(40-90)^{b /} \\
74(39-89)^{b}\end{array}$ & 52.44 & 2.39 (median) & $\begin{array}{l}\text { Gabapentin: the initial dose was } \\
300 \mathrm{mg} \text {, increased to } 3,600 \mathrm{mg} / \mathrm{day} \\
\text { at night from the fourth week }\end{array}$ & Identical placebo & $\begin{array}{l}\text { Mean sleep interference } \\
\text { scorec }^{c} \text { adverse effects }\end{array}$ & $\mathrm{RCT} ; 8$ \\
\hline $\begin{array}{l}\text { Rice } \\
\text { et al. (29) }\end{array}$ & $\begin{array}{l}\text { Postherpetic } \\
\text { neuralgia }\end{array}$ & 334 & $\begin{array}{l}76.3(36.1-90.8)^{d / /} \\
74.9(28.9-94.8)^{d}\end{array}$ & 41.32 & 2.19 (median) & $\begin{array}{l}\text { Gabapentin: the initial dose was } \\
300 \mathrm{mg} / \text { day, increased to } 1,800 \text { or } \\
2,400 \mathrm{mg} / \text { day within } 2 \text { weeks }\end{array}$ & Identical placebo & $\begin{array}{l}\text { Mean sleep interference } \\
\text { score; adverse effects }\end{array}$ & $\mathrm{RCT} ; 7$ \\
\hline $\begin{array}{l}\text { Garcia- } \\
\text { Borreguero } \\
\text { et al. (18) }\end{array}$ & RLS & 44 & $N R$ & $N R$ & $N R$ & $\begin{array}{l}\text { Gabapentin: the dose was initially } \\
600 \mathrm{mg} / \text { day and was adjusted every } \\
2 \text { weeks to a maximum dose of } \\
2,400 \mathrm{mg} / \text { day ( } 1200 \text { hours and } \\
2000 \text { hours) }\end{array}$ & Identical placebo & $\begin{array}{l}\text { Pittsburgh sleep quality } \\
\text { index global score } \\
\text { (44); polysomnography } \\
\text { parameters; adverse effects }\end{array}$ & $\begin{array}{l}\text { RCT; } 6 \text { (excluding the } \\
\text { washout period and } \\
\text { crossover period) }\end{array}$ \\
\hline $\begin{array}{l}\text { Gordh } \\
\text { et al. (19) }\end{array}$ & Neuropathic pain & 120 & NR & NR & $\geq 0.5$ & $\begin{array}{l}\text { Gabapentin: the initial dose was } \\
300 \mathrm{mg} / \text { day, increased to } 2,400 \mathrm{mg} / \\
\text { day from the third week }\end{array}$ & Identical placebo & $\begin{array}{l}\text { Mean sleep interference } \\
\text { score } \text {; adverse effects }\end{array}$ & $\begin{array}{l}\text { RCT; } 5 \text { (excluding the } \\
\text { washout period and } \\
\text { crossover period) }\end{array}$ \\
\hline $\begin{array}{l}\text { Lal } \\
\text { et al. (25) }\end{array}$ & RLS & 217 & $48.0 \pm 12.70$ & 64.06 & $13.39 \pm 13.68$ & $\begin{array}{l}\text { Gabapentin enacarbil: the initial dose } \\
\text { was } 600 \mathrm{mg} / \text { day, increased to } 1,200 \text {, } \\
1,800 \text {, or } 2,400 \mathrm{mg} / \text { day within } 9 \text { days }\end{array}$ & Identical placebo & $\begin{array}{l}\text { Post-sleep questionnaire; } \\
\text { tolerability assessments }\end{array}$ & $\mathrm{RCT} ; 12$ \\
\hline $\begin{array}{l}\text { Mason } \\
\text { et al. (27) }\end{array}$ & $\begin{array}{l}\text { Alcohol } \\
\text { dependence }\end{array}$ & 150 & $44.53 \pm 11.01$ & 56.67 & $14.43 \pm 9.85$ & $\begin{array}{l}\text { Gabapentin: the initial dose was } \\
300 \mathrm{mg} / \text { day, increased to } 900 \text { or } \\
1,800 \mathrm{mg} / \text { day within } 6 \text { days }\end{array}$ & Identical placebo & $\begin{array}{l}\text { Pittsburgh sleep quality } \\
\text { index global score (44); } \\
\text { adverse effects }\end{array}$ & $\mathrm{RCT} ; 12$ \\
\hline $\begin{array}{l}\text { Bone } \\
\text { et al. (40) }\end{array}$ & Phantom limb pain & 19 & $56.25 \pm 17.5$ & 78.95 & 1.5 (median) & $\begin{array}{l}\text { The first phase was gabapentin treatment } \\
\text { (12 weeks): the initial dose was } 300 \mathrm{mg} / \\
\text { day, gradually increased to } 2,400 \mathrm{mg} / \\
\text { day; the second phase was placebo } \\
\text { treatment ( } 6 \text { weeks), with } 1 \text { week of } \\
\text { washout between the two phases }\end{array}$ & $\begin{array}{l}6 \text { weeks of placebo } \\
\text { treatment and } \\
12 \text { weeks of } \\
\text { gabapentin treatment }\end{array}$ & $\begin{array}{l}\text { Mean sleep interference } \\
\text { score; adverse effects }\end{array}$ & $\begin{array}{l}\text { RCT plus crossover; } \\
18\end{array}$ \\
\hline
\end{tabular}




\begin{tabular}{|c|c|c|c|c|c|c|c|c|c|}
\hline \multirow[t]{2}{*}{ Reference } & \multicolumn{5}{|c|}{ Participants } & \multicolumn{2}{|l|}{ Intervention } & \multirow[t]{2}{*}{ Sleep outcome } & \multirow{2}{*}{$\begin{array}{l}\text { Study design and } \\
\text { treatment duration } \\
\text { (weeks) }\end{array}$} \\
\hline & Diagnoses & $\begin{array}{l}\text { Sample } \\
\text { size }\end{array}$ & Age (years) $^{a}$ & $\begin{array}{c}\text { Male } \\
(\%)\end{array}$ & $\begin{array}{l}\text { Illness } \\
\text { duration } \\
\text { (years) }\end{array}$ & Gabapentin group & Control group & & \\
\hline $\begin{array}{l}\text { Backonja } \\
\text { et al. (15) }\end{array}$ & Diabetic neuralgia & 165 & $53 \pm 10.32$ & 60 & $11.61 \pm 9.15$ & $\begin{array}{l}\text { Gabapentin: } 900 \mathrm{mg} / \text { day for the first } \\
\text { week, increased to } 3,600 \mathrm{mg} / \text { day } \\
\text { from the fourth week }\end{array}$ & Identical placebo & $\begin{array}{l}\text { Mean sleep interference } \\
\text { scorec; adverse effect }\end{array}$ & RCT; 8 \\
\hline $\begin{array}{l}\text { Arnold } \\
\text { et al. (14) }\end{array}$ & Fibromyalgia & 150 & $48.25 \pm 11.22$ & 90 & $\geq 0.5$ & $\begin{array}{l}\text { Gabapentin: } 300 \text { mg before bedtime } \\
\text { at the first week, increased to } \\
600 \text { mg twice a day plus } 1,200 \mathrm{mg} \\
\text { before bedtime from the } \\
\text { sixth week }\end{array}$ & Identical placebo & $\begin{array}{l}\text { Medical outcomes study } \\
\text { sleep problems index score } \\
\text { (45); adverse effects }\end{array}$ & $\mathrm{RCT} ; 12$ \\
\hline $\begin{array}{l}\text { Winkelman } \\
\text { et al. (36) }\end{array}$ & RLS & 272 & $52.0 \pm 12.7$ & 41.98 & NR & $\begin{array}{l}\text { Gabapentin enacarbil: } 600 \mathrm{mg} / \text { day } \\
\text { initially, increased to } 1,200 \mathrm{mg} / \text { day } \\
\text { from the fourth day to the end of the } \\
\text { first } 4 \text { weeks, followed by another } \\
\text { 4-week placebo treatment phase after } \\
\text { a } 7 \text {-day dose-decreasing period and a } \\
\text { 7-day washout period }\end{array}$ & $\begin{array}{l}4 \text { weeks of identical } \\
\text { placebo, followed by } \\
4 \text { weeks of gabapentin } \\
\text { enacarbil treatment } \\
\text { after } 2 \text { weeks of } \\
\text { washout }\end{array}$ & $\begin{array}{l}\text { Polysomnography } \\
\text { parameters; subjective } \\
\text { post-sleep diary; tolerability } \\
\text { assessments }\end{array}$ & $\begin{array}{l}\text { RCT plus } \\
\text { crossover; } 8\end{array}$ \\
\hline $\begin{array}{l}\text { Vieta } \\
\text { et al. (33) }\end{array}$ & Bipolar disorder & 25 & $46.87 \pm 14.74$ & 28 & $18.79 \pm 10.90$ & $\begin{array}{l}\text { Gabapentin: } 1,200 \mathrm{mg} / \text { day initially, } \\
\text { adjusted to } 900 \mathrm{mg} / \text { day within } 1 \text { week } \\
\text { according to the symptoms and } \\
\text { patient tolerance }\end{array}$ & Identical placebo & $\begin{array}{l}\text { Pittsburgh sleep quality } \\
\text { index global score (44); } \\
\text { adverse effects }\end{array}$ & $\mathrm{RCT} ; 54$ \\
\hline $\begin{array}{l}\text { Pinkerton } \\
\text { et al. (28) }\end{array}$ & $\begin{array}{l}\text { Hot flashes in } \\
\text { menopause }\end{array}$ & 593 & $54 \pm 6.05$ & 0 & $\geq 2$ & $\begin{array}{l}\text { Gabapentin: } 600 \mathrm{mg} / \text { day initially, } \\
\text { increased to } 1,800 \mathrm{mg} / \text { day }(600 \mathrm{mg} \\
\text { with breakfast and } 1,200 \mathrm{mg} \text { with the } \\
\text { evening meal) from the seventh day }\end{array}$ & Identical placebo & 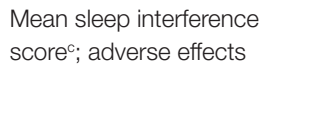 & $\mathrm{RCT} ; 24$ \\
\hline $\begin{array}{l}\text { Wallace } \\
\text { et al. (34) }\end{array}$ & $\begin{array}{l}\text { Postherpetic } \\
\text { neuralgia }\end{array}$ & 400 & $66.67 \pm 12.55$ & 52 & $\geq 0.25$ & $\begin{array}{l}\text { Gabapentin: } 1,800 \mathrm{mg} \text { at night for } \\
\text { Group } 1 \mathrm{and} 600 \mathrm{mg} \text { in the morning } \\
\text { and 1,200 } \mathrm{mg} \text { at night for Group } 2\end{array}$ & Identical placebo & 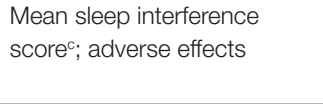 & $\mathrm{RCT} ; 10$ \\
\hline $\begin{array}{l}\text { Irving } \\
\text { et al. (22) }\end{array}$ & $\begin{array}{l}\text { Postherpetic } \\
\text { neuralgia }\end{array}$ & 158 & $69.37 \pm 11.59$ & 46.84 & $\geq 0.25$ & $\begin{array}{l}\text { Gabapentin: } 1,800 \mathrm{mg} \text { at night for } \\
\text { Group } 1 \mathrm{and} 600 \mathrm{mg} \text { in the morning } \\
\text { and } 1,200 \mathrm{mg} \text { at night for } \\
\text { Group } 2\end{array}$ & Identical placebo & $\begin{array}{l}\text { Mean sleep interference } \\
\text { scorec; adverse effects }\end{array}$ & $\mathrm{RCT} ; 4$ \\
\hline $\begin{array}{l}\text { Lee } \\
\text { et al. (26) }\end{array}$ & RLS & 322 & $48.95 \pm 12.56$ & 58.60 & $15.56 \pm 12.09$ & $\begin{array}{l}\text { Gabapentin enacarbil: } 600 \mathrm{mg} / \text { day for } \\
\text { Group } 1 \text { and } 1,200 \mathrm{mg} / \text { day (once daily } \\
\text { at 5:00 p.m. for Group 2) }\end{array}$ & Identical placebo & $\begin{array}{l}\text { Pittsburgh sleep diary, post- } \\
\text { sleep questionnaire; adverse } \\
\text { effects }\end{array}$ & $\mathrm{RCT} ; 12$ \\
\hline $\begin{array}{l}\text { Kushida } \\
\text { et al. (23) }\end{array}$ & RLS & 221 & $51.12 \pm 12.80$ & 40.27 & $14.07 \pm 13.78$ & $\begin{array}{l}\text { Gabapentin(XP13512) } 1,200 \mathrm{mg} \text { once } \\
\text { daily at 5:00 p.m. }\end{array}$ & Identical placebo & $\begin{array}{l}\text { Medical outcomes study } \\
\text { sleep problems index } \\
\text { score (45); post-sleep } \\
\text { questionnaire; Pittsburgh } \\
\text { Sleep Diary (46); adverse } \\
\text { effects }\end{array}$ & $\mathrm{RCT} ; 12$ \\
\hline
\end{tabular}


TABLE $1 \mid$ Continued

\begin{tabular}{|c|c|c|c|c|c|c|c|c|c|}
\hline \multirow[t]{2}{*}{ Reference } & \multicolumn{5}{|c|}{ Participants } & \multicolumn{2}{|l|}{ Intervention } & \multirow[t]{2}{*}{ Sleep outcome } & \multirow{2}{*}{$\begin{array}{l}\text { Study design and } \\
\text { treatment duration } \\
\text { (weeks) }\end{array}$} \\
\hline & Diagnoses & $\begin{array}{l}\text { Sample } \\
\text { size }\end{array}$ & Age (years) ${ }^{a}$ & $\begin{array}{c}\text { Male } \\
(\%)\end{array}$ & $\begin{array}{l}\text { Illness } \\
\text { duration } \\
\text { (years) }\end{array}$ & Gabapentin group & Control group & & \\
\hline $\begin{array}{l}\text { Kushida } \\
\text { et al. (23) }\end{array}$ & RLS & 76 & $50.1 \pm 13.2$ & 42.11 & $14.30 \pm 14.09$ & $\begin{array}{l}\text { Gabapentin(XP13512) 1,800 mg/day } \\
\text { during Period } 1 \text { followed by placebo } \\
\text { during Period } 2\end{array}$ & $\begin{array}{l}\text { Placebo during } \\
\text { Period 1, followed by } \\
\text { Gabapentin (XP13512) } \\
\text { 1,800 mg/day during } \\
\text { Period } 2\end{array}$ & $\begin{array}{l}\text { Polysomnography } \\
\text { parameters; adverse effects }\end{array}$ & $\begin{array}{l}\text { RCT plus crossover; } \\
4\end{array}$ \\
\hline $\begin{array}{l}\text { Walters } \\
\text { et al. (35) }\end{array}$ & RLS & 95 & $50.44 \pm 11.17$ & 37.89 & $16.0 \pm 13.11$ & $\begin{array}{l}\text { Gabapentin enacarbil: the dose } \\
\text { was } 600 \mathrm{mg} / \text { day for Group } 1 \text { and } \\
1,200 \mathrm{mg} / \text { day (once a day at 5:00 } \\
\text { p.m.) for Group } 2\end{array}$ & Identical placebo & $\begin{array}{l}\text { Post-sleep questionnaire; } \\
\text { adverse effects }\end{array}$ & $\mathrm{RCT} ; 2$ \\
\hline $\begin{array}{l}\text { Backonja } \\
\text { et al. (16) }\end{array}$ & $\begin{array}{l}\text { Postherpetic } \\
\text { neuralgia }\end{array}$ & 102 & $64.47 \pm 12.47$ & 45.54 & $3.27 \pm 4.11$ & $\begin{array}{l}\text { Gabapentin enacarbil: 1,200 mg twice } \\
\text { daily }\end{array}$ & Identical placebo & $\begin{array}{l}\text { Mean sleep interference } \\
\text { scorec; adverse effects }\end{array}$ & $\mathrm{RCT} ; 2$ \\
\hline $\begin{array}{l}\text { Sang } \\
\text { et al. (32) }\end{array}$ & $\begin{array}{l}\text { Postherpetic } \\
\text { neuralgia }\end{array}$ & 450 & $65.61 \pm 12.22$ & 37.39 & $1.68 \pm 1.17$ & $\begin{array}{l}\text { Gastroretentive gabapentin: } 1,800 \mathrm{mg} / \\
\text { day }\end{array}$ & Identical placebo & $\begin{array}{l}\text { Mean sleep interference } \\
\text { scorec; adverse effects }\end{array}$ & $\mathrm{RCT} ; 11$ \\
\hline $\begin{array}{l}\text { Sandercock } \\
\text { et al. (31) }\end{array}$ & Diabetic neuralgia & 147 & $58.68 \pm 8.24$ & 55.10 & $10.14 \pm 8.72$ & $\begin{array}{l}\text { Gastroretentive gabapentin: } 3,000 \mathrm{mg} \\
\text { at night for Group } 1 \mathrm{and} 1,200 \mathrm{mg} \text { in } \\
\text { the morning and 1,800 } \mathrm{mg} \text { at night for } \\
\text { Group } 2\end{array}$ & Identical placebo & $\begin{array}{l}\text { Mean sleep interference } \\
\text { scorec; adverse effects }\end{array}$ & $\mathrm{RCT} ; 4$ \\
\hline $\begin{array}{l}\text { Bogan } \\
\text { et al. (17) }\end{array}$ & RLS & 190 & $51.45 \pm 11.90$ & 59.07 & $14.01 \pm 14.13$ & $\begin{array}{l}\text { Gabapentin enacarbil: } 1,200 \mathrm{mg} \text { once } \\
\text { daily }\end{array}$ & $\begin{array}{l}\text { Gabapentin enacarbil } \\
\text { at a dose of } 600 \mathrm{mg} \\
\text { and one tablet of } \\
\text { placebo during the first } \\
2 \text { weeks, two placebo } \\
\text { tablets from the third } \\
\text { week }\end{array}$ & $\begin{array}{l}\text { Post-sleep questionnaire } \\
\text { (23); medical Outcomes } \\
\text { Study Sleep Scale; kilogram } \\
\text { effects }\end{array}$ & $\begin{array}{l}\text { RCT; } 12 \text { (excluding } \\
\text { the open-label period) }\end{array}$ \\
\hline $\begin{array}{l}\text { Yurcheshen } \\
\text { et al. (37) }\end{array}$ & $\begin{array}{l}\text { Hot flashes in } \\
\text { menopause }\end{array}$ & 59 & $52.85 \pm 3.34$ & 0 & $4.17 \pm 3.77$ & Gabapentin: 300 mg three times daily & Identical placebo & $\begin{array}{l}\text { Pittsburgh Sleep Quality } \\
\text { Index global score (44); } \\
\text { adverse effects }\end{array}$ & $\mathrm{RCT} ; 12$ \\
\hline
\end{tabular}

$R C T$, randomized controlled trial; $R L S$, restless legs syndrome; NR, not reported.

aResults are shown as the mean $\pm S D$.

${ }^{b}$ Results are shown as the median (interquartile ranges).

'The range is $0-10$, with $0=$ no sleep interference and $10=$ worst possible sleep interference.

${ }^{d}$ Results are shown as the mean (range).

${ }^{\text {The }}$ range is $0-100$, with $0=$ no sleep interference and $100=$ worst possible sleep interference. 
the posttreatment values of the evaluation indices provided in the trials in which the index values increased and the trials in which the index values decreased (none of these trials provided the baseline values), respectively. Composite Endpoint 5 (Excellent, 0 or Good) represented the sleep outcomes that received the highest grades in the survey, e.g., the overall quality of sleep was evaluated as "Excellent," or the ability to function was evaluated as "Good," or the number of nighttime awakenings caused by RLS symptoms was 0 , or the number of hours awake per night because of RLS symptoms was 0 in the past week. Composite Endpoint 6 (Poor, $\geq 3$, $\geq 5$, or 7 ) represented the sleep outcomes that were graded the lowest in the survey, e.g., the overall quality of sleep was evaluated as "Poor," or the ability to function was evaluated as "Poor," or the number of nighttime awakenings caused by RLS symptoms was $\geq 5$, or the number of hours awake per night because of RLS symptoms was $\geq 3$, or the number of nights with RLS symptoms was 7 in the past week.

\section{Quality Assessment}

Two investigators evaluated the methodological quality of all included trials according to the Cochrane Collaboration's tool for assessing bias [the Reviewer's Handbook (39)].

\section{Grading of Recommendations Assessment, Development, and Evaluation (GRADE) Classification}

Based on the GRADE study group criteria (20), we graded the evidence quality for all of the endpoints.

\section{Data Synthesis and Analysis}

Based on the formula and endpoint definition, the values of the same endpoints in each trial were pooled first and then the data from different trials were pooled together for analysis. The standardized mean difference (SMD) and risk ratio (RR) were used to assess the abovementioned endpoints. Prior to the metaanalysis of each endpoint, statistical heterogeneity across the various trials was tested using Chi-square test. A $P$-value greater than the nominal level of 0.10 and $I^{2} \leq 40 \%$ indicated a lack of heterogeneity across trials, allowing for the use of a fixed-effects model; otherwise, a random-effects model was used. The inverse variance method was used for continuous variables, and the Mantel-Haenszel method was used for dichotomous variables. In addition, a sensitivity analysis was conducted by removing each trial one at a time, and the publication bias was evaluated using the Egger test.

SPSS Predictive Analytics Software version 18.0 (SPSS, Inc., Chicago, IL, USA) was used for the Chi-square tests, and Stata Statistical Software version SE 12.0 (Stata Corp. LP, College Station, TX, USA) was used for all other analyses.

\section{RESULTS}

\section{Search Results and Trial Characteristics}

Ninety-eight records were identified through database searches and were screened by reading titles, abstracts, and part of main text. After irrelevant papers, observational studies, duplicates, and trials that used non-placebo control drugs were excluded, 26 papers $(13-19,21-37,40,41)$ met the inclusion criteria. The included publications comprised eight RLS-related trials, eight neuropathic pain-related trials, and three alcohol dependencerelated trials, two trials involving hot flashes in menopause, one fibromyalgia-related trial, one trial involving phantom limb pain, one trial involving HIV-associated sensory neuropathies, and one bipolar disorder-related trial. Among the included studies, six trials were included only for systematic review and 20 trials were included for meta-analysis.

The included 26 trials involved 4,684 patients. The average follow-up length was 11.07 weeks/per patient, and the total followup time was 997.23 patient-years. The average age of $83.50 \%$ of the patients was $55.45( \pm 13.45)$ years. Among $96.50 \%$ of patients,

TABLE 2 | Efficacy comparison of gabapentin and placebos.

\begin{tabular}{|c|c|}
\hline Trials & Endpoints \\
\hline Kushida et al. (23) & $\begin{array}{l}\text { Compared with the placebo group, the gabapentin group } \\
\text { showed significant improvement in sleep quality }(P<0.001) \text {, } \\
\text { next-day functioning }(P<0.001) \text {, number of nighttime } \\
\text { awakenings caused by RLS symptoms ( } P=0.043) \text {, and } \\
\text { number of hours awake due to RLS symptoms }(P=0.019) \\
\text { after } 12 \text { weeks of treatment; the gabapentin group had } \\
\text { a significantly prolonged total sleep time after } 2 \text { weeks } \\
\text { of treatment ( } P=0.003) \text {, but there was no statistically } \\
\text { significant difference between the two groups after } 12 \text { weeks } \\
\text { of treatment }(P=0.187)\end{array}$ \\
\hline
\end{tabular}

Lee et al. (26) Compared with the placebo group, the patients who received the treatment at a dose of $600 \mathrm{mg}$ had a significantly shortened average daily wake time after sleep onset at all studied time points $(P<0.05)$ with no increase in their total sleep time $(P>0.05)$

Hahn et al. (21) Compared with the placebo group, the gabapentin group showed a significantly improved mean sleep interference score $(P<0.05)$

Lal et al. (25) Compared with the placebo group, the gabapentin group showed a significant improvement in all sleep indices (an excellent overall quality of sleep, an excellent ability to function, fewer nights with RLS symptoms, fewer awakenings during the night, 0 or less than $1 \mathrm{~h}$ awake per night because of RLS symptoms)

Mason et al. (27) Compared with the placebo group, the gabapentin group $(1,800 \mathrm{mg})$ had a significantly improved Pittsburgh Sleep Quality Index total score $(P<0.001)$

Rice et al. (29) Compared with the placebo group, the gabapentin group $(1,800$ and $2,400 \mathrm{mg})$ had a significantly improved mean sleep interference score $(P<0.01)$

Bone et al. (40) In terms of the mean sleep interference score, neither the gabapentin group nor the placebo group showed a statistically significant difference $(P>0.05)$

Brower et al. (41) Compared with before treatment, the gabapentin group and the placebo group showed improvement in the subjective indices (Sleep Problems Questionnaire, sleep diaries) and the objective indices (polysomnography parameters: sleep onset latency, sleep efficiency, wake time after sleep onset, total sleep time, percentage of sleep spent in Stage 1, percentage of sleep spent in Stage 2, percentage of slow-wave sleep, and percentage of rapid eye movement sleep), but there was no statistically significant difference between the two groups $(P>0.05)$ 
males accounted for $42.73 \%$; among $90.67 \%$ of patients, the average length of disease course was at least $6.23( \pm 9.76)$ years. The initial dose of gabapentin was 300 or $600 \mathrm{mg} /$ day; after the dose-increasing phase, the minimum dose was $600 \mathrm{mg} /$ day and the maximum dose was $3,600 \mathrm{mg} /$ day, with an average dose of $1,793.92 \mathrm{mg} /$ day. Figure $\mathbf{1}$ presents the screening process used in the study, Table $\mathbf{1}$ lists the main characteristics of all included trials.

\section{Quality Assessment}

There were seven trials $(14,16,18,19,32,33,41)(26.92 \%)$ with random sequence generation $(14,16,18,19,22,32,33,41)$
(30.77\%) with allocation concealment, eight trials $(14,16,18$, $19,22,32,33,41)(30.77 \%)$ with blinding of participants, and three trials $(16,32,41)(11.54 \%)$ with blinding of personnel treating the patients and outcome assessors. Except for the 26 trials above that had unclear risks, the trials included in this study had low risks of bias (Figures S1 and S2 in Supplementary Material).

\section{Efficacy}

A pooled analysis of eight trials $(21,23,25-27,29,40,41)$ demonstrated that other than some indicators in three trials $(26,40,41)$, gabapentin showed a treatment efficacy superior

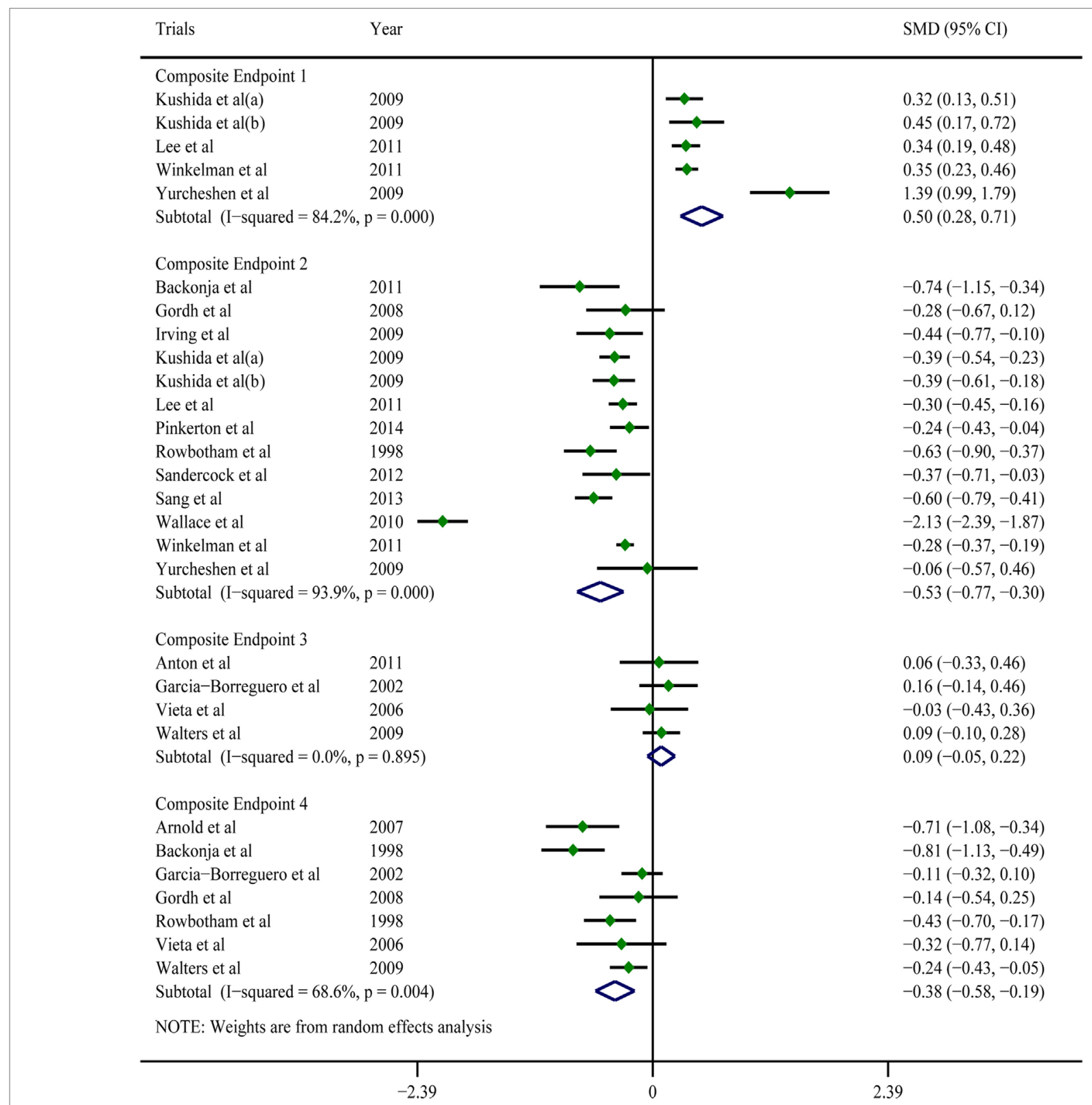

FIGURE 2 | Forest plots of Composite Endpoint 1, Composite Endpoint 2, Composite Endpoint 3, and Composite Endpoint 4. Except for Composite Endpoint 3, the treatment effects of gabapentin were superior to those of the placebo; a random-effects model. 
to that of the placebos in all trials (Table 2). Regarding multiple subjective and objective sleep indices, the meta-analyses indicated that, except for Composite Endpoint 3 (13, 18, $33,35)$ [SMD $=0.09,95 \%$ confidence interval (CI): $-0.05-0.22]$, Composite Endpoint $1(23,24,26,36,37)$, Composite Endpoint $2(16,19,22-24,26,28,30-32,34,35,37)$, Composite Endpoint $4(14,15,18,19,30,33,35)$, Composite Endpoint $5(17,26)$, and Composite Endpoint $6(17,26)$ confirmed that gabapentin's treatment efficacy was superior to that of the placebos (Figures 2 and 3).

\section{Tolerability}

All of the trials reported mild-to-moderate adverse effects. The moderate adverse effects occurred primarily during the dose-increasing phase and significantly decreased in frequency afterward. Drowsiness, dizziness, and weakness were the most frequently reported effects. These discomforts were tolerable for the majority of patients but resulted in drug withdrawal in a portion of patients. A meta-analysis of 20 trials (7, 14-17, 19, 21, 22, $25-28,32-37)$ showed that for adverse events that were possibly or probably related to the study drug and could lead to treatment discontinuation and drug withdrawal, the gabapentin group had a 1.45-times higher risk than the placebo group ( $R R=1.38 ; 95 \%$ CI: 1.08-1.76; Figure 3); For adverse events that were possibly or probably related to the study drug and could lead to treatment discontinuation and drug withdrawal, the incidences in the gabapentin group and the placebo group were 8.19 and $5.37 \%$ $(P<0.001)$, respectively. Sixteen trials $(14,17,19,21,22,25-29$, $31-34,36)$ reported serious adverse effects. However, other than one case of headache (34), one case of serious dizziness and

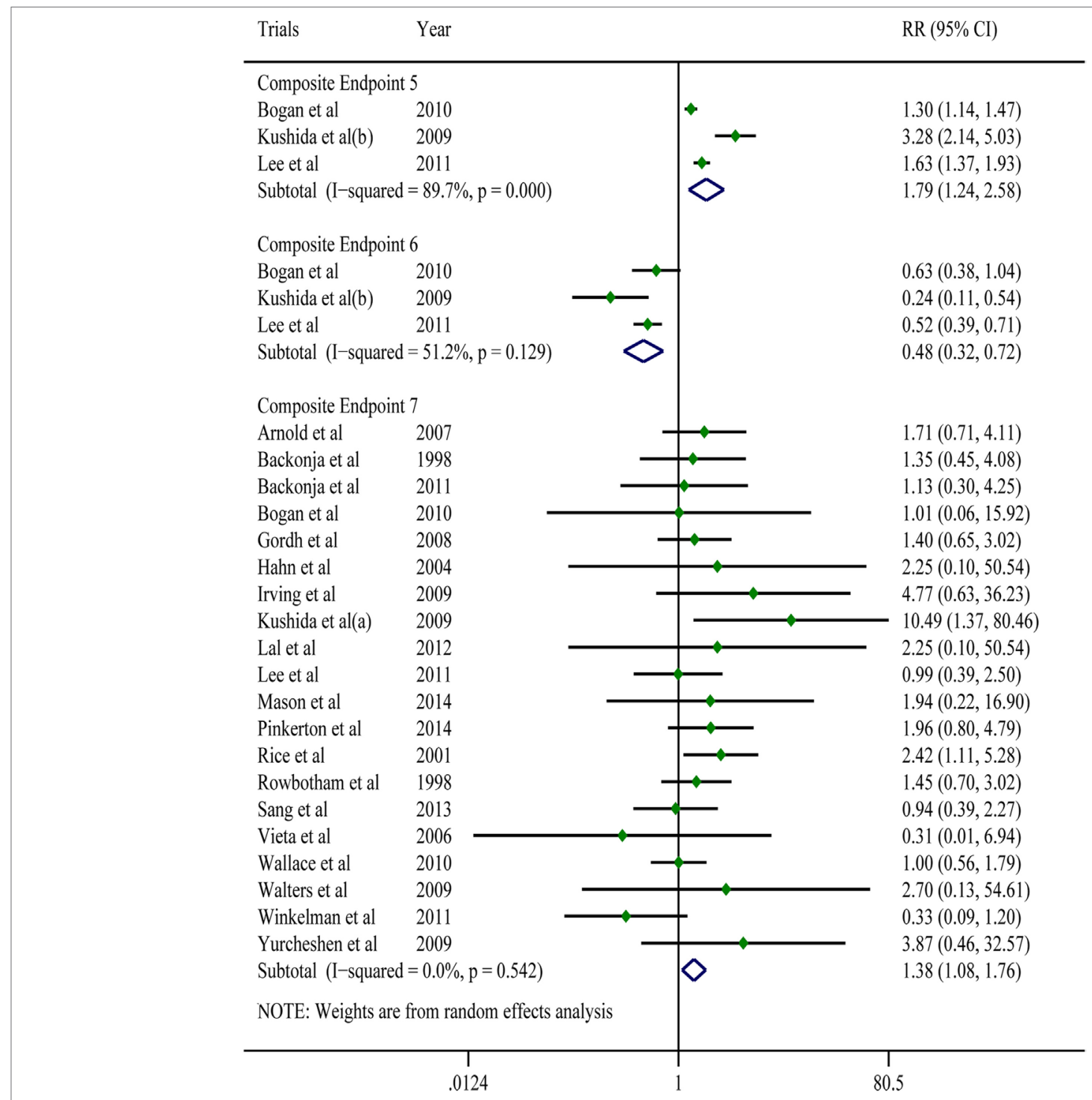

FIGURE 3 | Forest plots of Composite Endpoint 5, Composite Endpoint 6 and Composite Endpoint 7. The treatment effects of gabapentin were superior to those of the placebo; the tolerability of gabapentin was lower than that of the placebo; a random-effects model. 
drowsiness (21), and one case of vision disturbance (19), no serious adverse effects were associated with the use of gabapentin. No serious adverse events associated with the use of placebos were found.

\section{GRADE Classification}

For the GRADE classifications of evidence quality, the high, moderate, low, and extremely low were $0,3,3$, and 0 , respectively (Table 3).

\section{Sensitivity Analysis}

The sensitivity analysis indicated that, for Composite Endpoint 1, the removal of any one trial led to a lower limit of the CI of SMD that was higher than 0; for Composite Endpoint 2 and Composite Endpoint 4, the removal of any one trial led to an upper limit of the CI of SMD that was lower than 0; for Composite Endpoint 5 and Composite Endpoint 7, the removal of any one trial led to a lower limit of the CI of the RR that was higher than 1 ; for Composite Endpoint 6, the removal of any one trial led to the lower limit of the CI of the RR that was lower than 1 (Figures S3-S8 in Supplementary Material). The above results suggest that the results for these endpoints were robust and had a low sensitivity.

\section{Publication Bias}

The $P$ values of all endpoints derived from the Egger test were greater than 0.05 , indicating there was no publication bias (Table 4).

\section{DISCUSSION}

This study revealed that without consideration of the type of sleep outcomes, gabapentin was significantly superior to placebos for the treatment for sleep disorders secondary to RLS, neuropathic pain, alcohol dependence, hot flashes in menopause, fibromyalgia, phantom limb pain, HIV-associated sensory neuropathies, and bipolar disorder. However, with an average dose of approximately $1,800 \mathrm{mg} /$ day, gabapentin had a higher risk of treatment discontinuation and drug withdrawal compared with placebo.

The above conclusion was drawn from an extensive summary of trials involving various primary diseases. Only a small portion of these trials reported the baseline sleep status $(14,18,21,26$,

TABLE 3 | Summary of the ratings regarding the quality of evidence.

\begin{tabular}{|c|c|c|c|c|c|}
\hline \multirow[t]{3}{*}{ Outcomes } & \multicolumn{2}{|c|}{ Illustrative comparative risks ${ }^{a}(95 \% \mathrm{Cl})$} & \multirow{3}{*}{$\begin{array}{l}\text { Relative effect } \\
\qquad(95 \% \mathrm{Cl})\end{array}$} & \multirow{3}{*}{$\begin{array}{c}\text { No of participants } \\
\text { (studies) }\end{array}$} & \multirow{3}{*}{$\begin{array}{l}\text { Quality of the } \\
\text { evidence [Grading of } \\
\text { Recommendations } \\
\text { Assessment, Development } \\
\text { and Evaluation (GRADE)] }\end{array}$} \\
\hline & Assumed risk & Corresponding risk & & & \\
\hline & Placebo & Gabapentin & & & \\
\hline $\begin{array}{l}\text { Composite Endpoint } \\
1 \text { follow-up: mean } \\
9.67 \text { weeks }\end{array}$ & & $\begin{array}{l}\text { The mean Composite Endpoint } 1 \text { in the } \\
\text { intervention groups was } 0.53 \text { SDs higher } \\
(0.41-0.66 \text { higher) }\end{array}$ & & 2,797 (5 studies) & $\oplus \oplus \oplus \ominus$ moderate ${ }^{b}$ \\
\hline $\begin{array}{l}\text { Composite Endpoint } \\
2 \text { follow-up: mean } \\
10.28 \text { weeks }\end{array}$ & & $\begin{array}{l}\text { The mean Composite Endpoint } 2 \text { in the } \\
\text { intervention groups was } 0.45 \text { SDs lower } \\
\text { (0.61-0.3 lower) }\end{array}$ & & 5,841 (13 studies) & $\oplus \oplus \ominus \ominus l o w^{b, c}$ \\
\hline $\begin{array}{l}\text { Composite Endpoint } \\
4 \text { follow-up: mean } \\
8.09 \text { weeks }\end{array}$ & & $\begin{array}{l}\text { The mean Composite Endpoint } 4 \text { in the } \\
\text { intervention groups was } 0.53 \text { SDs lower } \\
\text { (0.69-0.36 lower) }\end{array}$ & & 1,501 (7 studies) & $\oplus \oplus \ominus \ominus l o w^{b, c}$ \\
\hline $\begin{array}{l}\text { Composite Endpoint } \\
5 \text { follow-up: mean } \\
10.97 \text { weeks }\end{array}$ & $\begin{array}{l}\text { Study population } \\
309 \text { per 1,000 } \\
\text { Moderate }\end{array}$ & 526 per 1,000 (383-798) & RR 1.7 (1.24-2.58) & 2,910 (3 studies) & $\oplus \oplus \ominus \ominus l o w^{b, c}$ \\
\hline $\begin{array}{l}\text { Composite Endpoint } \\
6 \text { follow-up: mean } \\
10.97 \text { weeks }\end{array}$ & $\begin{array}{l}\text { Study population } \\
122 \text { per } 1,000 \\
\text { Moderate }\end{array}$ & 59 per 1,000 (39-88) & RR $0.48(0.32-0.72)$ & 2,910 (3 studies) & $\oplus \oplus \oplus \ominus$ moderate ${ }^{c}$ \\
\hline $\begin{array}{l}\text { Composite Endpoint } \\
7 \text { follow-up: mean } \\
11.60 \text { weeks }\end{array}$ & $\begin{array}{l}\text { Study population } \\
54 \text { per } 1,000 \\
\text { Moderate }\end{array}$ & 74 per 1,000 (58-94) & RR 1.38 (1.08-1.76) & 4,097 (20 studies) & $\oplus \oplus \oplus \ominus$ moderate ${ }^{c}$ \\
\hline
\end{tabular}

aThe basis for the assumed risk (e.g., the median control group risk across studies) is provided in footnotes. The corresponding risk

(and its 95\% confidence interval) is based on the assumed risk in the comparison group and the relative effect of the intervention (and its 95\% Cl).

$\mathrm{Cl}$, confidence interval; $R R$, risk ratio.

GRADE Working Group grades of evidence.

High quality: further research is very unlikely to change our confidence in the estimate of effect.

Moderate quality: further research is likely to have an important impact on our confidence in the estimate of effect and may change the estimate.

Low quality: further research is very likely to have an important impact on our confidence in the estimate of effect and is likely to change the estimate.

Very low quality: we are very uncertain about the estimate.

${ }^{b}$ The differences exist among the trial's objects.

${ }^{\circ}$ The variation in point estimates among different trials was relatively large, and the heterogeneity

test showed results of $P<0.10$ and $R^{2}>40 \%$. 
TABLE 4 | Results of the Egger test.

\begin{tabular}{|c|c|c|c|c|c|c|}
\hline Results & $\begin{array}{l}\text { Composite } \\
\text { Endpoint } 1\end{array}$ & Composite Endpoint 2 & Composite Endpoint 4 & Composite Endpoint 5 & Composite Endpoint 6 & Composite Endpoint 7 \\
\hline$P$-value & 0.241 & 0.053 & 0.063 & 0.138 & 0.567 & 0.336 \\
\hline $95 \% \mathrm{Cl}$ & $-8.18-3.04$ & $-0.12-14.04$ & $-18.67-0.69$ & $-11.28-23.83$ & $-32.97-29.02$ & $-0.51-1.43$ \\
\hline
\end{tabular}

$\mathrm{Cl}$, confidence interval.

$27,36,37,41)$, and none of these trials reported the sleep status prior to the disease. Because it was impossible to distinguish absolutely true, partially true, and false sleep disturbance, we could not exclude the contribution of false sleep disturbance to the final treatment efficacy in patients with medical illness. However, it is worth noting that more than $90 \%$ of the patients in these trials had an average disease course of 6.23 ( \pm 9.76$)$ years. In terms of the psychological aspects of insomnia, the intention to fall sleep often becomes a driving factor of sleep difficulty (47) and worries about being sleepless often cause early awakening or anxiety (48), particularly among patients who are prone to excessive worry or over thinking. Without timely correction, one episode of sleep difficulty can easily induce a second episode in patients with related psychological traits, and as a result, ongoing sleep difficulties ultimately lead to a chronic sleep disorder. Some researchers believe that the initiating event does not significantly affect the progression of chronic sleep disorders (49) and that chronic sleep disorders are not closely associated with primary disease and thus do not improve with the improvement of the primary disease. In other words, during the chronic course of the abovementioned primary diseases, false sleep disturbance might have transformed into true or partially true sleep disturbance in patients with medical illness for the majority of the sample pool. Thus, we believe the existence of false sleep disturbance in medical illness would not significantly affect the results of the efficacy analysis, and the improvement of sleep disorders can be attributed to the efficacy of gabapentin treatment. The following experimental evidence supports this deduction: gabapentin can shorten sleep latency (36), reduce awakenings (12, 26, $35,36)$, reduce fast-wave sleep (23), enhance slow-wave sleep (9-12, 18, 36), prolong the total sleep time $(18,23,36)$, increase sleep efficiency $(12,18,36)$, and improve the quality of sleep $(17,23,35,36)$. In fact, because of its sedative effect in various diseases, gabapentin has been clinically used as a hypnotic (48). Nevertheless, its efficacy for primary sleep disorders remains to be verified by randomized controlled trials, and the optimal dosage that is effective and tolerable in most patients needs to be identified.

It is necessary to emphasize that despite its insignificant impact on the progression of sleep disorders, the initial sleep difficulty can induce the recurrence of disease (49). In other words, the complete cure of sleep disorders requires a complete removal of the initiating stimulus. Therefore, the use of gabapentin in the abovementioned diseases can "kill two birds with one stone."

Moreover, it is worth noting that pooled statistics were used with the basic premise of analyzing the efficacy of gabapentin. In this study, we introduced the concept of "composite endpoints" to pool sleep-outcome data that had similar significance and consistent direction. In a broad sense, this research method is in accordance with the basic principle of meta-analysis (39).

\section{Research Significance}

Through a systematic review and meta-analysis, this study for the first time systematically evaluated the clinical value of gabapentin for the treatment of sleep disorders. Used as a starting point, this study could inspire more researchers to conduct in-depth research on this topic.

\section{Study Limitations}

Because of the difficulty of distinguishing false sleep disturbance from true ones in patients with medical illness, we were unable to exclude their contribution to the treatment efficacy. In addition, because of the limitations of the original trials, we were unable to conduct a meta-analysis of individual sleep outcomes and analyses related to treatment dose and timing or patient gender.

\section{CONCLUSION}

This is the first study to systematically evaluate the clinical value of gabapentin for the treatment of sleep disorders. Regardless the type of sleep outcomes, gabapentin showed stable efficacy in the treatment for sleep disturbance in patients with medical illness with a relatively high risk of treatment discontinuation and drug withdrawal when used at an average dose of approximately $1,800 \mathrm{mg} /$ day. Because the adverse events often occurred during the dose-increasing phase, and the dose was high, reducing the dose-increasing speed and lowering the dosage of gabapentin might reduce the risk. In addition, it would be ideal if our conclusions could be further verified in patients with primary sleep disorders.

\section{AUTHOR CONTRIBUTIONS}

All authors contributed equally to this work.

\section{ACKNOWLEDGMENTS}

We greatly appreciate the help of Dr. Hui Nie from Durham of North Carolina, USA with the translation of this manuscript. Also thanks to Dr Hui Hui Wu and Dr Shao Hua Cheng of Taihe Hospital for their help.

\section{FUNDING}

Y-FW was support by the foundation of Hubei province public welfare science and technology research project 
(2012DCA12006), and LD was supported by the foundation of health and family planning commission of Hubei province (WJ2015MB222). Role of the Funding Source: The research results and conclusions were not affected by the financial support.

\section{REFERENCES}

1. Laugsand LE, Strand LB, Platou C, Vatten LJ, Janszky I. Insomnia and the risk of incident heart failure: a population study. Eur Heart J (2014) 35:1382-93. doi:10.1093/eurheartj/eht019

2. Parthasarathy S, Vasquez MM, Halonen M, Bootzin R, Quan SF, Martinez FD, et al. Persistent insomnia is associated with mortality risk. Am J Med (2015) 128:268.e-75.e. doi:10.1016/j.amjmed.2014.10.015

3. Sofi F, Cesari F, Casini A, Macchi C, Abbate R, Gensini GF. Insomnia and risk of cardiovascular disease: a meta-analysis. Eur J Prev Cardiol (2014) 21:57-64. doi:10.1177/2047487312460020

4. Daley M, Morin CM, LeBlanc M, Gregoire JP, Savard J. The economic burden of insomnia: direct and indirect costs for individuals with insomnia syndrome, insomnia symptoms, and good sleepers. Sleep (2009) 32:55-64. doi:10.1016/j. sleep.2008.04.005

5. Hillman DR, Lack LC. Public health implications of sleep loss: the community burden. Med J Aust (2013) 199:S7-10. doi:10.5694/mja13.10620

6. Kuriyama A, Honda M, Hayashino Y. Ramelteon for the treatment of insomnia in adults: a systematic review and meta-analysis. Sleep Med (2014) 15:385-92. doi:10.1016/j.sleep.2013.11.788

7. Winkler A, Auer C, Doering BK, Rief W. Drug treatment of primary insomnia: a meta-analysis of polysomnographic randomized controlled trials. CNS Drugs (2014) 28:799-816. doi:10.1007/s40263-014-0198-7

8. Lana B, Schlick B, Martin S, Pratt WS, Page KM, Goncalves L, et al. Differential upregulation in DRG neurons of an alpha2delta-1 splice variant with a lower affinity for gabapentin after peripheral sensory nerve injury. Pain (2014) 155:522-33. doi:10.1016/j.pain.2013.12.001

9. Foldvary-Schaefer N, De Leon Sanchez I, Karafa M, Mascha E, Dinner D, Morris HH. Gabapentin increases slow-wave sleep in normal adults. Epilepsia (2002) 43:1493-7. doi:10.1046/j.1528-1157.2002.21002.x

10. Jain SV, Glauser TA. Effects of epilepsy treatments on sleep architecture and daytime sleepiness: an evidence-based review of objective sleep metrics. Epilepsia (2014) 55:26-37. doi:10.1111/epi.12597

11. Legros B, Bazil CW. Effects of antiepileptic drugs on sleep architecture: a pilot study. Sleep Med (2003) 4:51-5. doi:10.1016/s1389-9457(02)00217-4

12. Lo HS, Yang CM, Lo HG, Lee CY, Ting H, Tzang BS. Treatment effects of gabapentin for primary insomnia. Clin Neuropharmacol (2010) 33:84-90. doi:10.1097/WNF.0b013e3181cda242

13. Anton RF, Myrick H, Wright TM, Latham PK, Baros AM, Waid LR, et al. Gabapentin combined with naltrexone for the treatment of alcoholdependence. Am J Psychiatry (2011) 168:709-17. doi:10.1176/appi.ajp.2011.10101436

14. Arnold LM, Goldenberg DL, Stanford SB, Lalonde JK, Sandhu HS, Keck PE Jr, et al. Gabapentin in the treatment of fibromyalgia: a randomized, double-blind, placebo-controlled, multicenter trial. Arthritis Rheum (2007) 56:1336-44. doi:10.1002/art.22457

15. Backonja M, Beydoun A, Edwards KR, Schwartz SL, Fonseca V, Hes M, et al. Gabapentin for the symptomatic treatment of painful neuropathy in patients with diabetes mellitus: a randomized controlled trial. JAMA (1998) 280:1831-6. doi:10.1001/jama.280.21.1831

16. Backonja MM, Canafax DM, Cundy KC. Efficacy of gabapentin enacarbil vs placebo in patients with postherpetic neuralgia and a pharmacokinetic comparison with oral gabapentin. Pain Med (2011) 12:1098-108. doi:10.1111/j. 1526-4637.2011.01139.x

17. Bogan RK, Bornemann MA, Kushida CA, Tran PV, Barrett RW. Long-term maintenance treatment of restless legs syndrome with gabapentin enacarbil: a randomized controlled study. Mayo Clin Proc (2010) 85:512-21. doi:10.4065/mcp.2009.0700

18. Garcia-Borreguero D, Larrosa O, de la Llave Y, Verger K, Masramon X, Hernandez G. Treatment of restless legs syndrome with gabapentin: a

\section{SUPPLEMENTARY MATERIAL}

The Supplementary Material for this article can be found online at http://journal.frontiersin.org/article/10.3389/fneur.2017.00316/ full\#supplementary-material.

double-blind, cross-over study. Neurology (2002) 59:1573-9. doi:10.1212/ WNL.59.10.1573

19. Gordh TE, Stubhaug A, Jensen TS, Arnèr S, Biber B, Boivie J, et al. Gabapentin in traumatic nerve injury pain: a randomized, double-blind, placebo-controlled, cross-over, multi-center study. Pain (2008) 138:255-66. doi:10.1016/j. pain.2007.12.011

20. Guyatt GH, Oxman AD, Schunemann HJ, Tugwell P, Knottnerus A. GRADE guidelines: a new series of articles in the Journal of Clinical Epidemiology. J Clin Epidemiol (2011) 64:380-2. doi:10.1016/j.jclinepi.2010.09.011

21. Hahn K, Arendt G, Braun JS, von Giesen HJ, Husstedt IW, Maschke M, et al. A placebo-controlled trial of gabapentin for painful HIV-associated sensory neuropathies. J Neurol (2004) 251:1260-6. doi:10.1007/s00415-004-0529-6

22. Irving $G$, Jensen $M$, Cramer $M, W u$ J, Chiang YK, Tark M, et al. Efficacy and tolerability of gastric-retentive gabapentin for the treatment of postherpetic neuralgia: results of a double-blind, randomized, placebo-controlled clinical trial. Clin J Pain (2009) 25:185-92. doi:10.1097/AJP.0b013e3181934276

23. Kushida CA, Becker PM, Ellenbogen AL, Canafax DM, Barrett RW. Randomized, double-blind, placebo-controlled study of XP13512/ GSK1838262 in patients with RLS.Neurology (2009) 72:439-46. doi:10.1212/01. wnl.0000341770.91926.cc

24. Kushida CA, Walters AS, Becker P, Thein SG, Perkins AT, Roth T, et al. A randomized, double-blind, placebo-controlled, crossover study of XP13512/ GSK1838262 in the treatment of patients with primary restless legs syndrome. Sleep (2009) 32:159-68. doi:10.1093/sleep/32.2.159

25. Lal R, Ellenbogen A, Chen D, Zomorodi K, Atluri H, Luo W, et al. A randomized, double-blind, placebo-controlled, dose-response study to assess the pharmacokinetics, efficacy, and safety of gabapentin enacarbil in subjects with restless legs syndrome. Clin Neuropharmacol (2012) 35:165-73. doi:10.1097/ WNF.0b013e318259eac8

26. Lee DO, Ziman RB, Perkins AT, Poceta JS, Walters AS, Barrett RW. A randomized, double-blind, placebo-controlled study to assess the efficacy and tolerability of gabapentin enacarbil in subjects with restless legs syndrome. J Clin Sleep Med (2011) 7:282-92. doi:10.5664/JCSM.1074

27. Mason BJ, Quello S, Goodell V, Shadan F, Kyle M, Begovic A. Gabapentin treatment for alcohol dependence: a randomized clinical trial. JAMA Intern Med (2014) 174:70-7. doi:10.1001/jamainternmed.2013.11950

28. Pinkerton JV, Kagan R, Portman D, Sathyanarayana R, Sweeney M. Phase 3 randomized controlled study of gastroretentive gabapentin for the treatment of moderate-to-severe hot flashes in menopause. Menopause (2014) 21:567-73. doi:10.1097/GME.0b013e3182a7c073

29. Rice AS, Maton S. Gabapentin in postherpetic neuralgia: a randomised, double blind, placebo controlled study. Pain (2001) 94:215-24. doi:10.1016/ S0304-3959(01)00407-9

30. Rowbotham M, Harden N, Stacey B, Bernstein P, Magnus-Miller L. Gabapentin for the treatment of postherpetic neuralgia: a randomized controlled trial. JAMA (1998) 280:1837-42. doi:10.1001/jama.280.21.1837

31. Sandercock D, Cramer M, Biton V, Cowles VE. A gastroretentive gabapentin formulation for the treatment of painful diabetic peripheral neuropathy: efficacy and tolerability in a double-blind, randomized, controlled clinical trial. Diabetes Res Clin Pract (2012) 97:438-45. doi:10.1016/j.diabres.2012. 03.010

32. Sang CN, Sathyanarayana R, Sweeney M. Gastroretentive gabapentin (G-GR) formulation reduces intensity of pain associated with postherpetic neuralgia (PHN). Clin J Pain (2013) 29:281-8. doi:10.1097/AJP.0b013e318258993e

33. Vieta E, Manuel Goikolea J, Martínez-Arán A, Comes M, Verger K, Masramon X, et al. A double-blind, randomized, placebo-controlled, prophylaxis study of adjunctive gabapentin for bipolar disorder. J Clin Psychiatry (2006) 67:473-7. doi:10.4088/JCP.v67n0320 
34. Wallace MS, Irving G, Cowles VE. Gabapentin extended-release tablets for the treatment of patients with postherpetic neuralgia: a randomized, double-blind, placebo-controlled, multicentre study. Clin Drug Investig (2010) 30:765-76. doi:10.2165/11539520-000000000-00000

35. Walters AS, Ondo WG, Kushida CA, Becker PM, Ellenbogen AL, Canafax DM, et al. Gabapentin enacarbil in restless legs syndrome: a phase 2b, 2-week, randomized, double-blind, placebo-controlled trial. Clin Neuropharmacol (2009) 32:311-20. doi:10.1097/WNF.0b013e3181b3ab16

36. Winkelman JW, Bogan RK, Schmidt MH, Hudson JD, DeRossett SE, HillZabala CE. Randomized polysomnography study of gabapentin enacarbil in subjects with restless legs syndrome. Mov Disord (2011) 26:2065-72. doi: $10.1002 / \mathrm{mds} .23771$

37. Yurcheshen ME, Guttuso T Jr, McDermott M, Holloway RG, Perlis M. Effects of gabapentin on sleep in menopausal women with hot flashes as measured by a Pittsburgh Sleep Quality Index factor scoring model. J Womens Health (Larchmt) (2009) 18:1355-60. doi:10.1089/jwh.2008.1257

38. Liberati A, Altman DG, Tetzlaff J, Mulrow C, Gøtzsche PC, Ioannidis JP, et al. The PRISMA statement for reporting systematic reviews and meta-analyses of studies that evaluate health care interventions: explanation and elaboration. PLoS Med (2009) 6:e1000100. doi:10.1371/journal.pmed.1000100

39. Higgins JP, Green S. The Cochrane Handbook for Systematic Reviews of Interventions 5.1.0. (updated march 2011) The Cochrane Collaboration Website. (2016). Available from: http://handbook.cochrane.org

40. Bone M, Critchley P, Buggy DJ. Gabapentin in postamputation phantom limb pain: a randomized, double-blind, placebo-controlled, cross-over study. Reg Anesth Pain Med (2002) 27:481-6. doi:10.1097/00115550-20020900000007

41. Brower KJ, Myra Kim H, Strobbe S, Karam-Hage MA, Consens F, Zucker RA. A randomized double-blind pilot trial of gabapentin versus placebo to treat alcohol dependence and comorbid insomnia. Alcohol Clin Exp Res (2008) 32:1429-38. doi:10.1111/j.1530-0277.2008.00706.x
42. Bastien CH, Vallieres A, Morin CM. Validation of the Insomnia Severity Index as an outcome measure for insomnia research. Sleep Med (2001) 2:297-307. doi:10.1016/S1389-9457(00)00065-4

43. Johns MW. A new method for measuring daytime sleepiness: the Epworth sleepiness scale. Sleep (1991) 14:540-5. doi:10.1093/sleep/14.6.540

44. Buysse DJ, Reynolds CF III, Monk TH, Berman SR, Kupfer DJ. The Pittsburgh Sleep Quality Index: a new instrument for psychiatric practice and research. Psychiatry Res (1989) 28:193-213. doi:10.1016/0165-1781(89)90047-4

45. Hays RD, Stewart AL. Sleep measures. In: Stewart AL, Ware JE, editors. Measuring Functioning and Well-Being. Durham, NC: Duke University Press (1992). p. 232-59.

46. Monk TH, Reynolds CF, Kupfer DJ, Buysse DJ, Coble PA, Hayes AJ, et al. The Pittsburgh Sleep Diary. J Sleep Res (1994) 3:111-20. doi:10.1111/j. 1365-2869.1994.tb00114.x

47. Zhao ZX. Sleep disorders. 5th ed. In: Wang WZ, Luo ZM, editors. Neurology. Beijing: People's Medical Publishing House (2004). p. 256-64.

48. Fischer J, Dogas Z, Bassetti CL, Berg S, Grote L, Jennum P, et al. Standard procedures for adults in accredited sleep medicine centres in Europe. J Sleep Res (2012) 21:357-68. doi:10.1111/j.1365-2869.2011.00987.x

49. Zhang XH, Han F, Zhang Y, Wang LX. Principles and Practice of Sleep Medicine. 5th ed. Beijing: People’s Medical Publishing House (2010). 457,586,590 p.

Conflict of Interest Statement: The authors report no potential conflicts of interest with respect to the research, authorship, and/or publication of this article.

Copyright (C) $2017 \mathrm{Liu}$, Karim, Xu, Wang, Yang, Ding and Wang. This is an open-access article distributed under the terms of the Creative Commons Attribution License (CC BY). The use, distribution or reproduction in other forums is permitted, provided the original author(s) or licensor are credited and that the original publication in this journal is cited, in accordance with accepted academic practice. No use, distribution or reproduction is permitted which does not comply with these terms. 